Vol. 13 (2004): 46-53.

\title{
Selenium content of Finnish oats in 1997-1999: effect of cultivars and cultivation techniques
}

\author{
Merja Eurola, Veli Hietaniemi \\ MTT Agrifood Research Finland, Chemistry Laboratory, FIN-31600 Jokioinen, Finland, e-mail: merja.eurola@mtt.fi \\ Markku Kontturi \\ MTT Agrifood Research Finland, Plant Production Research, FIN-31600 Jokioinen, Finland \\ Hannu Tuuri \\ MTT Agrifood Research Finland, Data and Information Services, FIN-31600 Jokioinen, Finland \\ Arjo Kangas, Markku Niskanen \\ MTT Agrifood Research Finland, South Ostrobothnia Research Station, Alapääntie 104, FIN-61400 Ylistaro, Finland \\ Marketta Saastamoinen \\ Satafood Development Association, Risto Rytin katu 70 C, FIN-32700 Huittinen, Finland
}

\begin{abstract}
Se-supplemented fertilization is the main factor affecting the selenium $(\mathrm{Se})$ contents of cereals in Finland. Soil and climatic conditions determine the activity of selenate added to soils and bioavailability to plants. In the present study the Se contents and its variation in Finnish oats, the differences between oat cultivars and cultivation techniques were examined. The selenium ( $\mathrm{Se}$ ) contents of oats (Avena sativa L.) in Finland were examined during 1997-1999 in 3 types of trial: official variety, organic cultivation variety and organic vs. conventional cultivation trials. Farm samples were also examined. The mean Se contents of oats in official variety trials were $0.110,0.120$ and $0.160 \mathrm{mg} \mathrm{kg}^{-1}$ dry weight (dw) range $0.016-0.460 \mathrm{mg} \mathrm{kg}^{-1} \mathrm{dw}$ in 1997-1999, respectively. The mean Se contents in farm samples were 0.050 and $0.130 \mathrm{mg} \mathrm{kg}^{-1} \mathrm{dw}$ in 1998 and 1999 , ranging between $<0.010$ and 0.330 $\mathrm{mg} \mathrm{kg}^{-1} \mathrm{dw}$. Considerable regional and seasonal variations existed. The Se contents of oats were significantly higher in 1999 probably due to the combined effect of not increased fertilizer level (from 6 to $10 \mathrm{mg} \mathrm{Se} \mathrm{kg}^{-1}$ fertilizer) and very low precipitation in 1999. The Se contents of oats were significantly lower in organic cultivation, due to the absence of Se-supplemented fertilization. Significant $(\mathrm{P}<0.001)$ cultivar differences were detected in official variety trials. The cultivars Veli and Leila showed higher levels of Se.
\end{abstract}

Key words: Avena sativa, oats, selenium, cereals, cultivars, organic farming, fertilizers 
Vol. 13 (2004): 46-53.

\section{Introduction}

Oats (Avena sativa L.) have recently increased more importance as a functional cereal food due to beneficial physiological properties. Oat bran decreases serum cholesterol (Anderson et al. 1984) and blood glucose levels (Wood et al. 1990). Oats have also been shown to be suitable to dietary therapy for coeliac disease patients (Janatuinen et al. 1996 Hardman et al. 1997, Reunala et al. 1998). In animal nutrition oats serve as good quality feed for horses, hens, broilers, sheep and milking cows. The importance of selenium ( $\mathrm{Se}$ ) in animal and human nutrition is well known. Oat cultivation in Finland has gradually increased, attaining a level of 450000 ha in 2002. Currently, oat cultivars most generally used in Finland are Veli, Aarre, Roope and Leila, corresponding to $57 \%$ of oat cultivation (KTTK 2002).

Se is available to plants in inorganic form as selenate and selenite and organic form (Adriano 1986). Many factors influence the form of Se present in soils: soil $\mathrm{pH}$, soil type and texture, presence of ions, precipitation and climatic conditions (Gissel-Nielssen 1971, Adriano 1986, Gissel-Nielssen 1988, Vuori et al. 1989, Mikkelsen and Wan 1990, Yläranta 1993). For geochemical and climatic reasons soils in Finland are deficient in available Se (Koljonen 1975, Sippola 1979, Sillanpää and Jansson 1992). Typical features of agricultural soils in Finland include their relatively strong natural acidity (mean soil pH about 5.75; Erviö et al. 1990, MäkeläKurtto and Sippola 2002), low electrical conductivities and $\mathrm{CaCO}_{3}$ equivalents, and high organic carbon content (Sillanpää and Jansson 1992). Under conditions prevailing in Finland selenate is easily reduced selenite or even more reduced forms and strongly bound to iron and aluminium oxides, and organic matter. Only about $4 \%$ of the total Se supply is in soluble (hot-waterextractable) form (Yläranta 1993). The mean hotwater-extractable Se content in agricultural soils in 1998 was $0.010 \pm 0.005 \mathrm{mg} \mathrm{l}^{-1}$ (Mäkelä-Kurtto and Sippola 2002).
The first attempt to improve Finnish Se-situation was made in 1960s when domestic animal feeds were supplemented with Se. During the 1970 s the Se content of domestic agricultural products was still found to be exceptionally low and the Se intake of Finns was only about 25$30 \mu \mathrm{g}$ per day (Varo et al. 1980a). In $1984 \mathrm{Se}$ supplementation of compound fertilizers was started. The original target of Se supplementation of fertilizers was to raise the Se content of cereal grains to about $0.1 \mathrm{mg} \mathrm{kg}^{-1}$ and thus increase the Se intake in the population. It was also seen that other domestic food and feed items would be affected. During the intervention the Se supplementation level has been revised twice, the latest revision being from 6 to $10 \mathrm{mg} \mathrm{kg}^{-1}$ fertilizer in 1998 (Eurola and Hietaniemi 2000). However, Se supplementation does not affect organic cultivation where the use of compound, inorganic fertilizers is not allowed.

The aims of the present study were to determine the Se contents and its variation in Finnish oats, examine the differences between oat cultivars and compare organic and conventional cultivation techniques with respect to Se.

\section{Material and methods}

\section{Oat field trials}

Two types of trial were performed: official variety trials (1997-1999) in 8-10 locations throughout Finland and organic cultivation trials (19971998). The cultivars in official variety trials were Belinda, Kolbu, Leila, Roope, Salo and Veli. The organic cultivation trials included organic cultivation variety trials in 7 locations and comparison of organic and conventional cultivation in 6 locations. The cultivars were Aarre, Katri, Kolbu, Leila, Puhti, Roope, Veli and Yty. Organic and conventional cultivation were compared using 2 cultivars Veli and Puhti. In organic cultivation the preceding crop was clover to improve the nitrogen status of the soil. At Ruukki and 
Eurola, M. et al. Selenium in oats

Jokioinen animal manure was also used. More detailed information on the trials were published previously (Järvi et al. 2000). In general, the growing season for 1998 was rainy and cool and for 1997 and 1999 dry and warm.

\section{Farm samples}

Oat farm samples were received from the Plant Production Inspection Centre Grain Laboratory which annually collects samples from farmers for the Grain Quality Monitoring Project.

\section{Sample pretreatment and chemical analysis}

The grain samples were dried to a moisture content of $<14 \%$. The samples were sorted with a 2-mm sieve and hulled with a BT 459, hulling machine using air pressure at Boreal Plant Breeding Ltd. Broken groats were discarded. Oat groats were milled with a falling-number hammer mill, using a $1.0-\mathrm{mm}$ sieve and stored in the freezer until analysis. The farm samples were only milled, not sieved or hulled.

Dry matter content as dry weight (dw) was determined gravimetrically after oven-drying the sample for $2 \mathrm{~h}$ at $130 \pm 2{ }^{\circ} \mathrm{C}$. The precence of Se was determined with an electrothermal atomic absorption method (Kumpulainen et al. 1983). The oat samples were digested in a mixture of concentrated $\mathrm{HNO}_{3}, \mathrm{HClO}_{4}$ and $\mathrm{H}_{2} \mathrm{SO}_{4}, \mathrm{Se}(\mathrm{VI})$ was reduced to $\mathrm{Se}(\mathrm{IV})$ with $\mathrm{HCl}$ and extracted into methylisobutylketone (MIBK) and measured with a Varian SpetrAA 400 graphite furnace atomic absorption spectrometer. The analytical method is accredited and the samples analysed as duplicates. The reference material and blank were included in each digestion batch and measured with the samples. The Se concentration in ARC/CL wheat flour was $0.055 \pm 0.006 \mathrm{mg} \mathrm{kg}^{-1}$, the certified value being $0.055 \pm 0.14 \mathrm{mg} \mathrm{kg}^{-1}$ dw.

\section{Statistical analysis}

The statistical methods used were described previously (Eurola et al. 2003). Before performing the analyses, assumptions of group variances were checked in Box-Cox diagnostic plots, normality assumptions of errors was assessed with stem-and-leaf display and normal probability plot. The differences between the cultivars in variety and organic cultivation trials were analyzed using mixed linear models. The year, location and trial were analyzed as a random factor and cultivars as the fixed factor (Öfversten and Nikander 1996). The effects of farming systems (organic vs. conventional), cultivars (Veli and puhti) and their interactions were determined by analyses of variance according to the split plot design. The farming system and cultivars were analyzed as the fixed and location and year as the random factor. All analyses were performed using the SAS mixed, univariate and g-plot procedures.

\section{Results and discussion}

The mean Se contents of oats in official variety trials were $0.110,0.120$ and $0.160 \mathrm{mg} \mathrm{kg}^{-1} \mathrm{dw}$ (range 0.016-0.460 mg kg-1 dw) in 1997-1999, respectively. Considerable regional and seasonal variations existed (Table 1), due to differing soil and weather conditions and fertilization, which is the most important single factor affecting Se concentrations of oats and other cereals in Finland. The highest Se concentrations were found in oats grown in fine sandy soils in Mikkeli and clay soil in 1999 in Vihti, while the lowest concentrations occurred in mould and coarse silty soils in the northern research stations Ylistaro and Ruukki. Generally, the Se concentrations of agricultural soils in Finland tend to decrease northwards. In southern Finland clay soils with higher Se contents predominate and peat and organic soils are more abundant in northern Finland (Sippola 1979, Mäkelä-Kurtto 
Vol. 13 (2004): 46-53.

and Sippola 2002). However, the highest total soil Se concentrations in Finland have been found in clay and organogenic soils, the lowest in coarse mineral soils. Se in the clay and organogenic soils is strongly bound to the soil constituents (Yläranta 1985). In Yläranta's studies (1985), $4.6 \%$ of the total Se content was extracted from coarse mineral soils into hot water, which was over $20 \%$ more than extraction from clay or organogenic soils. Se applied as selenate may remain in the form available to plants in coarse mineral soils longer where the surface area is smaller and the soil more aerated. Selenate may also leach out of the root zone more easily from coarse soil types.

Generally, the Se contents of oats were significantly higher in 1999; the main reason is the effect of an increased fertilizer level (from 6 to

Table 1. Mean Se content of oat $\left(\mathrm{mg} \mathrm{kg}^{-1}\right)$ in official variety trials, precipitation, effective temperature sum, soil $\mathrm{pH}$ and type at different trial locations during 1997-1999.

\begin{tabular}{|c|c|c|c|c|c|c|}
\hline Location & Year & $\begin{array}{c}\text { Precipitation } \\
\text { May-Aug } \\
\text { mm }\end{array}$ & $\begin{array}{c}\text { Effective } \\
\text { temperature } \\
\text { sum }\end{array}$ & Soil $\mathrm{pH}$ & Soil type & $\begin{array}{c}\text { Se content } \\
\text { mg kg-1 dry weight } \\
\text { Mean } \pm \text { SD }\end{array}$ \\
\hline \multirow[t]{3}{*}{ Jokioinen } & 1997 & 302 & 1217 & 6.3 & sandy clay & $0.030 \pm 0.007$ \\
\hline & 1998 & 318 & 1011 & 5.8 & clay & $0.070 \pm 0.009$ \\
\hline & 1999 & 146 & 1184 & 5.7 & sandy clay & $0.180 \pm 0.030$ \\
\hline \multirow[t]{3}{*}{ Mietoinen 1} & 1997 & 232 & 1285 & 5.3 & clay & $0.030 \pm 0.004$ \\
\hline & 1998 & 245 & 1036 & 5.9 & sandy clay & $0.110 \pm 0.009$ \\
\hline & 1999 & 92 & 1236 & 5.8 & sandy clay & $0.170 \pm 0.030$ \\
\hline Mietoinen 2 & 1999 & 92 & 1236 & 6.3 & clay & $0.100 \pm 0.010$ \\
\hline \multirow[t]{2}{*}{ Tuusula } & 1997 & n.a. & n.a. & 6.3 & sandy clay loam & $0.170 \pm 0.020$ \\
\hline & 1998 & n.a. & n.a. & 6.0 & coarse silt & $0.070 \pm 0.010$ \\
\hline \multirow[t]{3}{*}{ Pälkäne } & 1997 & 253 & 1250 & 5.7 & fine silt & $0.095 \pm 0.009$ \\
\hline & 1998 & 339 & 1043 & 6.0 & fine silt & $0.100 \pm 0.008$ \\
\hline & 1999 & 141 & 1231 & 5.9 & fine silt & $0.240 \pm 0.050$ \\
\hline \multirow[t]{3}{*}{ Mikkeli } & 1997 & 115 & 1150 & 6.9 & fine sand & $0.410 \pm 0.040$ \\
\hline & 1998 & 337 & 976 & 6.0 & fine sand & $0.230 \pm 0.030$ \\
\hline & 1999 & 243 & 1133 & 6.0 & fine sand & $0.200 \pm 0.010$ \\
\hline \multirow[t]{3}{*}{ Maaninka } & 1997 & 177 & 1153 & 5.8 & coarse silt & $0.130 \pm 0.020$ \\
\hline & 1998 & 340 & 938 & 6.1 & coarse silt & $0.050 \pm 0.006$ \\
\hline & 1999 & 183 & 1134 & 5.5 & coarse silt & $0.240 \pm 0.050$ \\
\hline \multirow[t]{3}{*}{ Laukaa } & 1997 & 182 & 1146 & 6.0 & coarse silt & $0.110 \pm 0.010$ \\
\hline & 1998 & 345 & 916 & 6.0 & coarse silt & $0.090 \pm 0.010$ \\
\hline & 1999 & 175 & 1112 & 6.0 & coarse silt & $0.180 \pm 0.020$ \\
\hline \multirow[t]{3}{*}{ Ylistaro 1} & 1997 & 155 & 1143 & 6.0 & sandy clay loam & $0.060 \pm 0.010$ \\
\hline & 1998 & 372 & 937 & 6.2 & silty clay & $0.060 \pm 0.010$ \\
\hline & 1999 & 120 & 1062 & 6.1 & silty clay & $0.180 \pm 0.040$ \\
\hline \multirow[t]{3}{*}{ Ylistaro 2} & 1997 & 155 & 1143 & 5.3 & mould & $0.020 \pm 0.003$ \\
\hline & 1998 & 372 & 937 & 5.7 & mould & $0.040 \pm 0.006$ \\
\hline & 1999 & 120 & 1062 & 5.5 & mould & $0.050 \pm 0.008$ \\
\hline \multirow[t]{2}{*}{ Ruukki 1} & 1998 & 439 & 850 & 5.9 & coarse silt & $0.050 \pm 0.003$ \\
\hline & 1999 & 182 & 952 & 5.4 & coarse silt & $0.050 \pm 0.010$ \\
\hline Ruukki 2 & 1999 & 182 & 952 & 5.4 & mould & $0.030 \pm 0.004$ \\
\hline \multirow[t]{2}{*}{ Vihti } & 1998 & 389 & 997 & 5.9 & coarse silt & $0.120 \pm 0.020$ \\
\hline & 1999 & 132 & 1173 & 6.2 & clay & $0.380 \pm 0.080$ \\
\hline
\end{tabular}

n.a. not available

SD standard deviation 
Eurola, M. et al. Selenium in oats

$10 \mathrm{mg} \mathrm{Se} \mathrm{kg}^{-1}$ fertiliser), but also the effect of very low precipitation in 1999. The cold and rainy growing season in 1997 probably decreased the Se contents of oats in some soil types due to increased leaching and reduction.

The effect of increased Se supplementation dosage in 1999 also clearly affected the oats during normal farming practices. The mean Se contents doubled in 1998-1999 from 0.050 to $0.130 \mathrm{mg} \mathrm{kg}^{-1} \mathrm{dw}$. The variation between farms was very large, $<0.010-0.110 \mathrm{mg} \mathrm{kg}^{-1} \mathrm{dw}(\mathrm{n}=$ $75)$ in 1998 and $<0.010-0.334 \mathrm{mg} \mathrm{kg}^{-1} \mathrm{dw}$ ( $\mathrm{n}=$ 88 ) in 1999. The Se concentrations during normal farming practices were generally slightly lower than in the research stations variety trials, where the fertilization levels and soil $\mathrm{pH}$ tended to be somewhat higher than those which generally occur in Finland. The farm samples were not hulled either. When the Se is mainly associated with the protein fraction of the grain it is more concentrated in the groats than in the grains. The mean Se contents of oats are currently very near the original Se supplementation target value for cereal grains, about $0.1 \mathrm{mg} \mathrm{kg}^{-1}$.

The Se concentrations found were similar to those occurring in previous Finnish studies performed during the period of Se fertilization. The Se contents of oats in 1972-1976 were found to be very low, generally below $<0.010 \mathrm{mg} \mathrm{kg}^{-1}$ $\mathrm{dw}$ (Varo et al. 1980b). After initiation of Se fertilization in 1985-1992, the Se contents of oat grains varied between 0.004 and $0.840 \mathrm{mg} \mathrm{kg}^{-1}$ dw. The highest values occurred in 1988-1989 when the mean Se concentrations of oat grains were 0.260 and $0.230 \mathrm{mg} \mathrm{kg}^{-1} \mathrm{dw}$, respectively (Ministry of Agriculture and Forestry 1994, Ekholm 1997).

\section{Organic vs. conventional cultivation}

Comparison of organic and conventional cultivation of oats was tested in the same field with cultivars Veli and Puhti (Fig. 1). The mean Se content in organic cultivation was $<0.010 \mathrm{mg}$ $\mathrm{kg}^{-1} \mathrm{dw}$ and in conventional cultivation $0.040 \mathrm{mg}$ $\mathrm{kg}^{-1} \mathrm{dw}$. The Se contents were distinctly lower during the rainy and cold growing season in 1998. The absence of Se fertilization was clearly seen. Organic cultivation resulted in significantly $(\mathrm{P}=0.006$, confidence interval -4.1 to -1.0) lower Se contents than conventional cultivation. The only exception occurred during the 1998 trial in Jokioinen where the Se contents were higher in organic cultivation for reasons that remain unclear. Some recent studies concerning organically grown foods have also shown very low Se contents in organically grown cereal and vegetable products (Eurola et al. 2000, Eurola and Ekholm 2002). This suggests that in organic animal production increased efforts are needed to ensure the sufficient Se content of feeds, especially when farm feeds are used.

\section{Cultivar differences}

Significant $(\mathrm{P}<0.001)$ cultivar differences were detected in official variety trials. Cultivars Veli and Leila had higher and cultivars Salo, Roope and Belinda lower Se contents than the other cultivars studied (Table 2). The difference between the mean Se concentrations of cultivars was $24 \%$. The Se content of Veli was also significantly $(\mathrm{P}=0.002)$ higher in organic vs. conventional cultivation trials. The effect of cultivar on Se contents in organic cultivation variety trials could not be analysed, since over $80 \%$ of the Se concentrations were below the detection

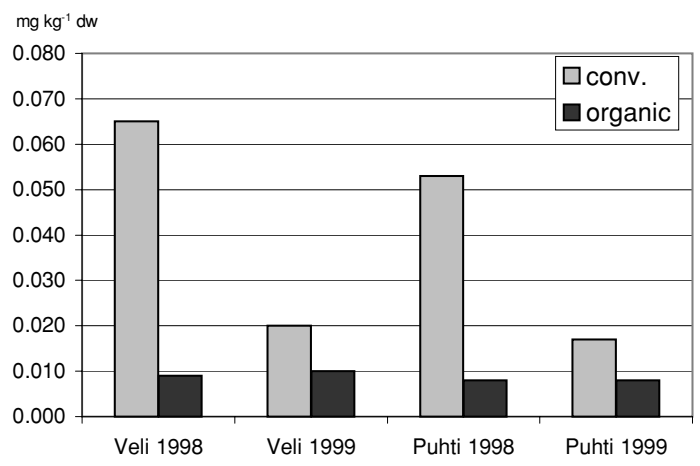

Fig. 1. Se contents $\left(\mathrm{mg} \mathrm{kg}^{-1}\right)$ of oats in organic and conventional cultivation during 1997-1998. 
Vol. 13 (2004): 46-53.

Table 2. Se content of oat cultivars $\left(\mathrm{mg} \mathrm{kg}^{-1}\right)$ in official variety trials $1997-1999$.

\begin{tabular}{|c|c|c|c|c|c|c|c|}
\hline Cultivar & 1997 & $\begin{array}{l}\text { Year } \\
1998\end{array}$ & 1999 & $\begin{array}{l}\text { Number } \\
\text { of trials }\end{array}$ & $\begin{array}{c}\text { All } \\
\text { original }^{\mathrm{a}}\end{array}$ & $\begin{array}{c}\text { All } \\
\log (x)\end{array}$ & $\begin{array}{c}\text { Standard Error } \\
\text { of means }\end{array}$ \\
\hline $\mathrm{n}$ & 52 & 55 & 56 & & & & \\
\hline Range & $0.016-0.460$ & $0.030-0.270$ & $0.016-0.460$ & & & & \\
\hline Veli & 0.130 & 0.100 & 0.190 & 31 & $0.140 \mathrm{a}$ & 4.67 & 0.132 \\
\hline Leila & 0.130 & 0.100 & 0.170 & 22 & $0.130 \mathrm{a}$ & 4.62 & 0.132 \\
\hline Kolbu & 0.100 & 0.060 & 0.130 & 32 & $0.120 \mathrm{~b}$ & 4.52 & 0.133 \\
\hline Roope & 0.100 & 0.070 & 0.160 & 32 & $0.120 b c$ & 4.51 & 0.133 \\
\hline Belinda & 0.110 & 0.080 & 0.160 & 21 & $0.120 b c$ & 4.50 & 0.133 \\
\hline Salo & 0.110 & 0.090 & 0.130 & 25 & $0.110 \mathrm{c}$ & 4.42 & 0.132 \\
\hline Median & 0.090 & 0.070 & 0.170 & 163 & 0.100 & & \\
\hline Mean & 0.110 & 0.090 & 0.160 & 163 & 0.110 & & \\
\hline
\end{tabular}

${ }^{a}$ Means followed by the same letter are not significantly different at $\mathrm{P}<0.05$

Statistical analyses are based on $\log$-transformed $(\log (\mathrm{x}))$ values.

limit. The Se levels were so low that any possible differences between the cultivars were insignificant.

In conclusion, the Se fertilization has significantly affected the Se content of cereals and other agricultural products in Finland. In the present study the mean Se contents of conventionally cultivated oats were at sufficient level and meat well the original Se supplementation target value for cereal grains, about $0.1 \mathrm{mg} \mathrm{kg}^{-1}$. However the Se contents varied considerably on annual basis and between different locations due to the variations in fertilizing rates and different soil and climatic conditions. In organic cultivation the Se contents of oats were very low, which should be noted in organic animal production. In official variety trials the cultivar significantly affected the Se contents of oats indicating the also presence of genetic variations. These existing differences make it possible to cultivate or develop cultivars likely to accumulate more Se, if necessary.

Acknowledgements. This study was supported by the Ministry of Agriculture and Forestry of Finland and the Finnish food and feed industry: Suomen Viljava Ltd., Kemira GrowHow and the Raisio Group. We thank Mrs. Leena Puura and Mr. Marko Ruusiala for their skilful technical help.

\section{References}

Adriano, D.C. 1986. Trace elements in the terrestial environment. 1st ed. New York: Springer-Verlag. 533 p.

Anderson, J.W., Story, L., Sieling, B., Chen, W.-J.L., Petro, M.S. \& Story, J. 1984. effects of oat bran or bean intake for hypocholesterolemic men. American Journal of Clinical Nutrition 40: 1146-1155.

Ekholm, P. 1997. Effects of selenium supplemented commercial fertilizers on food selenium contents and selenium intake in Finland. Academic dissertation. University of Helsinki. EKT-series 1047. 74 p.

Erviö, R., Mäkelä-Kurtto, R. \& Sippola, J. 1990. Chemical characteristics of Finnish agricultural soils in 1974 and in 1987. In: Kauppi, P. et al. (eds.). Acidification in Finland. Springer Verlag: Berlin, Germany. p. 217234.

Eurola, M. \& Ekholm, P. 2002. Seleeniä kotimaisista viljoista. Leipä Leveämmäksi 2(2002): 40-41.

Eurola, M., Hietaniemi, V., Kontturi, M., Tuuri, H., Pihlava, J.M., Saastamoinen, M., Rantanen, O., Kangas, A. \& Niskanen, M. 2003. Cadmium contents of oats (Avena sativa L.) in official variety, organic cultivation, and nitrogen fertilization trials during 1997-1999. Journal of Agricultural Food Chemistry 51: 26082614.

Eurola, M. \& Hietaniemi, V. 2000. Report of the selenium monitoring programme. 1998-1999. Publications of the Agricultural Research Centre of Finland. Series $B$ 24. Jokioinen, Finland. 25 p.

Eurola, M., Hirvi, T. \& Venäläinen, E.-R. 2000. Elintarvikkeiden seleenipitoisuus. In: Eurola, M. \& Hietaniemi, V. (eds.). Report of the selenium monitoring programme. 1998-1999. Publications of the Agricultural 


\section{AGRICULTURAL AND FOOD SCIENCE}

Eurola, M. et al. Selenium in oats

Research Centre of Finland. Series B 24. Jokioinen, Finland. $25 \mathrm{p}$.

Gissel-Nielssen, G. 1971. Influence of pH and texture of the soil on plant uptake of added selenium. Journal of Agricultural Food Chemistry 19: 1165-1167.

Gissel-Nielssen, G. 1988. Selenium in the soil-plant system. In: Neve, J. \& Favier, A. (eds.). Selenium in medicine and biology. Proceedings of the Second International Congress in Trace Elements in Medicine and Biology. Avoriaz, France: Walter de Gruyter.

Hardman, C., Garioch, J. \& Leonard, J. 1997. Absence of toxicity of oats in patients with dermatitis herpetiformis. New England Journal of Medicine 337: 18841887.

Janatuinen, E., Kemppainen, T., Kosma, V.M., Heikkinen, M., Julkunen, R. \& Uusitupa, M. 1996. Oats in coeliac diet; a 5-year follow-up study. In: Seventh International Symposium on Coeliac Disease. Tampere, Finland. Free paper Abstracts A128.

Järvi, A., Kangas, A., Laine, A., Niskanen, M., Salo, Y., Vuorinen, M., Jauhiainen, L., \& Mäkelä, L. 2000. Results of the official variety trials 1992-1999. Publications of Agrifood Research Finland, Series A, 70.216 p.

Koljonen, T. 1975. The behaviour of selenium in Finnish soils. Annales Agriculturae Fenniae 14: 240-247.

KTTK 2002. Grain quality in 2002. Plant Production Inspection Centre, Grain Laboratory, Helsinki. 75 p.

Kumpulainen, J., Raittila, A.M., Lehto, J. \& Koivistoinen, P. 1983. Electrothermal atomic absorption spectrometric determination of selenium in foods and diets. Jounal of Association Official Analytical Chemistry 66: 1129-1135.

Mäkelä-Kurtto, R. \& Sippola, J. 2002. Monitoring of Finnish arable land: changes in soil quality between 1987 and 1998. Agricultural and Food Science in Finland 11: 273-284.

Mikkelsen, R.L. \& Wan, H.F. 1990. The effect of selenium on sulphur uptake by barley and rice. Plant and Soil 121: 151-153.
Ministry of Agriculture and Forestry 1994. Seurantatulokset vuosilta 1991-1993. Työryhmämuistio MMM 1994:2, Helsinki. 36 p.

Öfversten, J. \& Nikander, H. 1996. Analysis of series of group variety trials. Publications of Agrifood Research Finland, Series B, 2. 27 p.

Reunala, T., Collin, P. \& Holm, K. 1998. Tolerance to oats in dermatitis herpetiformis. Gut 43: 490-493.

Sillanpää, M. \& Jansson, H. 1992. Status of cadmium, lead, cobalt and selenium in soils and plants of thirty countries. FAO Soils Bulletin 65. $195 \mathrm{p}$.

Sippola, J. 1979. Selenium content of soils and timothy (Phleum pratense L.) in Finland. Annales Agriculturae Fenniae 18: 182-187.

Varo, P., Nuurtamo, M., Saari, E. \& Koivistoinen, P. 1980a. Mineral element composition of Finnish foods. III. General discussion and nutritional evaluation. Acta Agriculturae Scandinavica, supplementum 22: 165171.

Varo, P., Nuurtamo, M., Saari, E. \& Koivistoinen, P. 1980b. Mineral element composition of Finnish foods. III. Annual variations in the mineral element composition of cereal grains. Acta Agriculturae Scandinavica, supplementum 22: 29-35.

Vuori, E., Vääriskoski, J., Hartikainen, H., Vakkilainen, P., Kumpulainen, J. \& Niinivaara, K. 1989. Sorption of selenate by Finnish agricultural soils. Agriculture, Ecosystems and Environment 25: 111-118.

Wood, P.J., Braaten, J.T., Scott, F.W., Riedel, D. \& Poste, L.M. 1990. Comparisons of viscous properties of oat and guar gum and effects of these and oat bran on glycemic index. Journal of Agricultural Food Chemistry 38: 753-757.

Yläranta, T. 1985. Increasing the selenium content of cereal and grass crops in Finland. Academic dissertation. Yliopistopaino, Helsinki. 72 p.

Yläranta, T. 1993. Selenium fertilization in Finland: selenium soil interactions. Norwegian Journal of Agricultural Science, suppl 11: 141-149. 
Vol. 13 (2004): 46-53.

\title{
SELOSTUS
}

\section{Suomalaisen kauran seleenipitoisuus vuosina 1997-1999}

\author{
Merja Eurola, Veli Hietaniemi, Markku Kontturi, Hannu Tuuri, Arjo Kangas, Markku Niskanen ja \\ Marketta Saastamoinen \\ MTT (Maa- ja elintarviketalouden tutkimuskeskus) ja Satafood Kehittämisyhdistys ry
}

Tutkimus oli osa Kaura raaka-aineen laadunohjausjärjestelmä -hanketta, jossa selvitettiin laajasti suomalaisen kauran laatua ja soveltuvuutta elintarvikeja rehukäyttöön. Tavoitteena oli selvittää kauran seleenipitoisuuksia sekä lajikkeen ja luomuviljelyn vaikutusta seleenipitoisuuksiin. Näyteaineisto koostui MTT:n tutkimusasemien ja yhteistyökumppanien kaurakokeiden satonäytteistä sekä seleeniseurantatutkimuksen yhteydessä Kasvintuotannon tarkastuskeskuksesta saaduista tilanäytteistä.

Virallisissa lajikekokeissa kauran keskimääräiset seleenipitoisuudet olivat $0,110,0,120$ and $0,160 \mathrm{mg}$ $\mathrm{kg}^{-1}$ kuiva-ainetta vuosina 1997-1999 vaihteluvälin ollessa $0,016-0,460 \mathrm{mg} \mathrm{kg}^{-1}$ kuiva-ainetta. Tilanäytteiden keskimääräiset seleenipitoisuudet olivat 0,050 and $0,130 \mathrm{mg} \mathrm{kg}^{-1}$ kuiva-ainetta vuosina 1998-1999, vaihteluväli $<0,010-0,330 \mathrm{mg} \mathrm{kg}^{-1} \mathrm{kuiva}^{-a i n e t t a . ~}$

Suomessa vuodesta 1984 alkanut seleenin lisääminen moniravinteisiin lannoitteisiin on tärkein viljojen seleenipitoisuuksiin vaikuttava tekijä. Vuonna 1998 seleenin määrää lannoitteissa nostettiin 6:sta 10 mg:aan kilossa, mikä näkyy myös tässä tutkimuksessa kauran suurempina seleenipitoisuuksina vuonna 1999. Myös maaperä ja ilmastolliset tekijät vaikuttavat liukoisen, kasveille käyttökelpoisen seleenin määrään maassa ja sitä kautta kauran seleenipitoisuuksien vaihteluun. Esimerkiksi satokausi 1998 oli hyvin sateinen ja viileä, jolloin seleenipitoisuudet jäivät monilla koepaikoilla pienemmiksi kuin muina tutkimusvuosina. Kauran keskimääräiset seleenipitoisuudet ovat nyt lähellä alkuperäistä seleenilannoitukselle asetettua tavoitetasoa, joka on viljoille $0,1 \mathrm{mg}$ $\mathrm{kg}^{-1}$.

Virallisissa lajikekokeissa eri lajikkeiden seleenipitoisuudet poikkesivat toisistaan selvästi. Veli- ja Leila-lajikkeiden seleenipitoisuudet olivat systemaattisesti suurempia kaikkina tutkimusvuosina. Luomulajikekokeissa lajikkeiden välisiä eroja ei voitu havaita, koska seleenipitoisuudet olivat alle määritysrajan, $0,010 \mathrm{mg} \mathrm{kg}^{-1}$. Seleenilannoituksen puute näkyy selvästi luomuviljelyssä, jossa kauran seleenipitoisuudet olivat pienempiä kuin tavanomaisessa viljelyssä. 